\title{
Perceived School Support in Inclusive Education
}

$$
\mathrm{DOI}=\underline{10.17556 / \text { ief.50307 }}
$$

\author{
Serhat ARSLAN*, Yıldıray KILIÇ**
}

\begin{abstract}
The aim of this study is to adapt Perceived School Support Scale in Inclusive Education (Ahmmed, 2013) to Turkish. In the scope of the research, adapted scale was applied to 221 teachers. In confirmatory factor analysis, it is observed that one dimensional model which consists of eight items adapted well. In order to examine the psychometric properties of the scale, internal consistency, item and factor analysis were conducted. Internal consistency analysis results of the scale is .85 were found, it was seen that the required rate was achieved with reliability by analyzes. Original single factor structure of PSSSIE (Perceived School Support Scale in İnclusive Education) was determined to comply with Turkish sample in accordance with the results from item distinctiveness and confirmatory factor analysis $\left(\mathrm{x}^{2}=97.57, \mathrm{sd}=20, \mathrm{RMSEA}=.133, \mathrm{NFI}=.92\right.$, NNFI $=.91, \mathrm{CFI}=.93$, IFI=.93,SRMR=066, GFI $=.90$ ).In this condition, for the Turkish sample group of the scale is expected to be applied to determine "Perceived School Support in İnclusive Education" levels of teachers in education process.
\end{abstract}

Keywords: Inclusive education, validity, reliability

\section{Özet}

$\mathrm{Bu}$ araştırmanın amacı Kaynaştırma Eğitiminde Algılanan Okul Desteği Ölçeğini (KEAODÖ) (Ahmmed, 2013) Türkçe 'ye uyarlamaktır. Araştırma kapsamında uyarlanan ölçek 221 öğretmene uygulanmıștır. Doğrulayıcı faktör analizinde 8 maddeden oluşan tek boyutlu modelin iyi uyum verdiği gözlemlenmiştir. Ölçeğin psikometrik özelliklerini inceleyebilmek amacıyla iç tutarlılık, madde ve faktör analizi çalışmaları yapılmıştır. Ölçeğin iç tutarlılık analizleri sonucu .85 bulunulmuş olup, yapılan analiz ile güvenirlik için gerekli olan orana ulaşıldığı görülmüştür. KEAODÖ'nin orijinal tek faktörlü yapısının, madde ayırt ediciliği ve doğrulayıcı faktör analizinden alınan sonuçlar doğrultusunda Türk örneklemine uygunluğu belirlenmiştir. $(x 2=97.57, \mathrm{sd}=20, \mathrm{RMSEA}=.133, \mathrm{NFI}=.92, \mathrm{NNFI}=.91$, $\mathrm{CFI}=.93, \mathrm{IFI}=.93, \mathrm{SRMR}=066, \mathrm{GFI}=.90) . \mathrm{Bu}$ durumda ölçeğin Türk örneklem grubu için eğitim sürecinde öğretmenlerin "Kaynaştırma Eğitiminde Algılanan Okul Desteği" düzeylerinin belirlenmesi için uygulanabileceği düşünülmektedir.

Anahtar Sözcükler: Kaynaştırma eğitimi, geçerlik ve güvenirlik. 


\section{Introduction}

Each individual needs education in order to survive socially and to be a productive individual. In the same way, finding a place in society and living independently of individuals who need special education is provided by education that will be given to them (Acar,2000). Special individuals are also members of the society and these individuals have right to take education such as people showing typical development. These individuals those will take the education, getting along with their peers with typical development will impact positively on their developments (Çetrez İşcan, Fazlıoğlu, Parlak, 2014). Considering the historical process in educational view, the first education taking environment of individuals who need special education were boarding/day care private schools. However,today, the importance given to education through mainstreaming and inclusive education has been adopted in our country and other countries (Kargin, 2004).Thus, to improve educational opportunities of children with special education needs and having disability, "Mainstreaming" has become a major policy planned (Linsdsay, 2007). However, the "Mainstreaming", as presumed, is not just that students with special needs are in the same classroom with typically developing peers.Besides, making certain adjustments in the environment, the implementation of the general principle, fulfilling the basic criteria and thus is adapted to the child's environment (Kargin, 2004). When the discourse about inclusive education is considered, it is quite important to provide appropriate education environment to prevent becoming an obstacle of disabilities of individuals who need special education and in case an individual's disability of skills (Yigen, 2008). A successful inclusive education program is concerned with individuals who have special needs taking a sufficient level of special education and normal education. To carry out inclusive education strictly, it is necessary to provide the necessary conditions and the presence of certain elements. These elements are teachers at school, students with typical development, students participating inclusive education, director and assistant 
director, families of students of inclusive education, the physical structure of classroom and school, families of students with typical development and support special education services (Batu\&KurcaaliIftar, 2007). However, in practice, teachers complain about the absence of these elements. When the ideas of teachers tutoring inclusive student related to facing problems in education of these children is evaluated entirely, educators' problems are indicated as lack of guidance support, inability of getting necessary help from director and assistant director, the excess numbers of students in classrooms, physical space limitations, problems appeared by families of students who take inclusive education, and being effected negatively children with typical development by students who take inclusive education (Demir \& Acar, 2011). Apart from all these elements, although having selfcritics of teachers in inclusive education process, adapting instruction while working with students having disability, teachers consider that there are insufficiencies in making frequent and irregular adaptations, cooperation between special education teachers, having competence for education to the students having disability (Kavale \& Forness, 2000). When all of them are considered, both homeroom teachers and branch teachers should be informed about inclusive education and these students before a student with special needs is put for inclusive education in their classes, and besides, they should be supported by special education experts during inclusive education process (Batu \& Kircaali-İftar, 2007).

\section{Research Design}

\section{Method}

This study is a scale adaptation and is conducted by survey method. The sample of the study was taken using Convenience sampling method. Convenience sampling method was used in order to choose the participants of the study group (Büyüköztürk, Kılıç Çakmak, Akgün, Karadeniz \& Demirel, 2012). 
As part of survey method, Turkish version form of Perceived School Support Scale in Inclusive Education (PSSSIE) was applied to teachers. The target population of this study includes teachers tutoring the students who are taking inclusive education. The study group involves 221 teachers who teach in province of Sakarya and Kocaeli. 126 numbers of teachers are female and 95 numbers of teachers are male.

\section{Instruments}

The Perceived School Support Scale in Inclusive Education; this measurement tool developed by Masud Ahmmed (2013) consists of eight items in one dimension. This scale is prepared Likert scale type with 5 points and items are from one to five and are ranked as "Never”, “Almost never”, "Somewhat”, “Adequately”, "Ultimate level”. 'Perceived School Support for Inclusive Education' (PSSIE) was created in order to measure teachers' perceptions of school support. The initial study includes information related to the developmental stages of the PSSIE scale consisting of item generation, content validation and statistical procedures. A four stage sampling method was used in order to select the sample group consisting of 1,387 primary school teachers from the Dhaka Division of Bangladesh. According to the results of the study, PSSIE( with eight items) was found as a reliable and useful instrument that can be used for measuring teachers' perceptions of school support in inclusive education. The reliability of the scale was estimated to be 0.86 . The mean inter-item correlation of PSSIE was found to be 0.43 , with values ranging from .29 to .59. In this scale, item means were found to range from 1.88 to 2.97 with a mean of 2.41. The mean-standard deviation for all items was 1.29, the lowest being 1.18, and the highest, 1.39. The Kaiser-Meyer-Olkin (KMO) measure of sampling adequacy index was found to be 0.9, The results of Exploratory factor analysis revealed the presence of one component with eigenvalues surpassing 1, explaining $50.28 \%$ of the variance. PSSSIE (Perceived School Support Scale in Inclusive Education) first was translated into Turkish and then necessary arrangements were done by examining translations. Later, items that were translated into Turkish were examined in terms of grammar and their meaning, incomplete parts are corrected and draft Turkish form was reached. Before validity and reliability study, PSSSIE's construct validity was examined as a validity work. For construct validity, con- 
firmatory factor analysis was conducted. PSSSIE's reliability was investigated with internal consistency and test retest methods, item analyses were examined with corrected item-total correlations. SPSS 22.0 and LISREL 8.71 (Jöreskog \& Sörbom, 1996) programs were used for validity and reliability analyses.

The original version of the scale was firstly translated into Turkish by three English teachers and the needed arrangements were done after the translations were examined. Turkish version of the scale was analyzed in terms of meaning and grammer and the trial form was reached. Various arrangements were done after the trial form was examined by three academicians in the field of educational sciences.

\section{Findings}

\section{Item Analysis and Reliability}

As a result of item analysis, internal consistency reliability coefficient of PSSSIEscale emerged as .85 for full scale. By conducting item analysis, it was aimed to identify the items which were belonged to PSSSIE, of the discriminating power. According to the results of analysis, items of the scale corrected total correlation coefficient were ranged between .47 and .68 Findings were shown in Table1.

Table-1.PSSSIE's Corrected İtem-Total Correlations

\begin{tabular}{|c|c|c|}
\hline \multicolumn{3}{|c|}{ Scale İtems İtem-Total Correlation $\left(r_{j x}\right)$} \\
\hline 1 & $\begin{array}{l}\text { Sınıf seviyesinde kaynaştırma eğtimi uygulamak için üst } \\
\text { düzey yetkililerden ( okul müdürü vs.) destek alırım. }\end{array}$ & .47 \\
\hline 2 & $\begin{array}{l}\text { Kaynaştırma yoluyla eğitimlerine devam öğrencilerimin okul } \\
\text { eğitimleri ile ilgili düzenli hizmet içi eğitim alırım. }\end{array}$ & .44 \\
\hline 3 & $\begin{array}{l}\text { Okulumda kaynaştırma eğitimini } \text { uygulamak için okul } \\
\text { idaresinden destek alırım. }\end{array}$ & .68 \\
\hline 4 & $\begin{array}{l}\text { Okulumda kaynaştırma eğitimini uygulamak için diğer öğret- } \\
\text { men arkadaşlarımdan destek alırım. }\end{array}$ & .65 \\
\hline
\end{tabular}




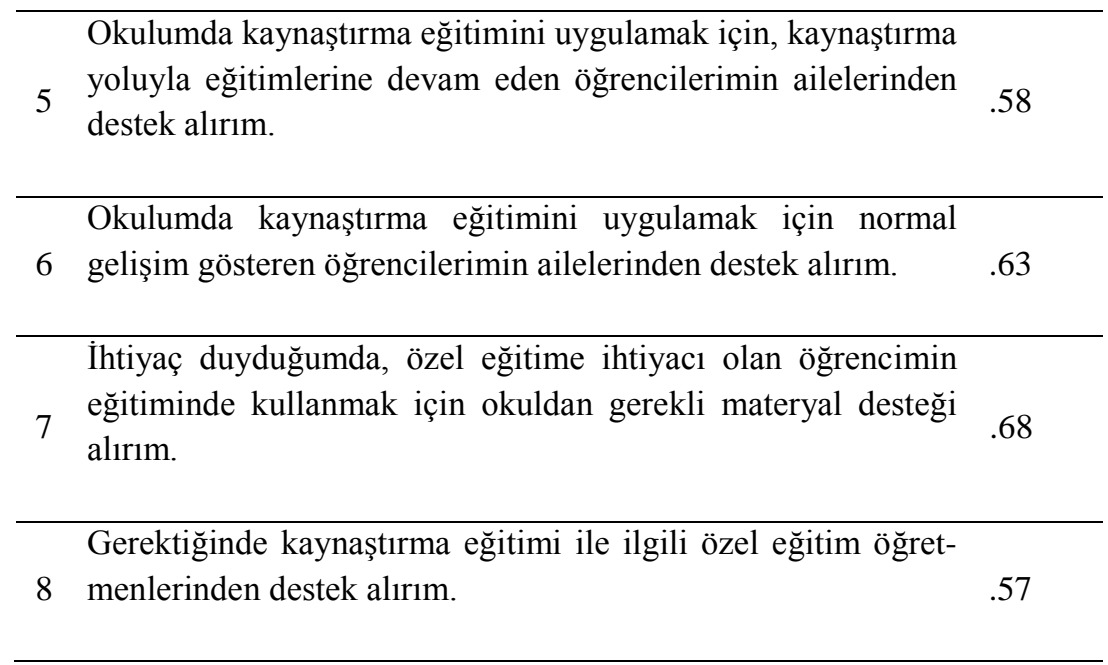

\section{Construct Validity}

For one dimensional model, applied confirmatory factor analysis result appearing fit indexvaluesare $x^{2}=97.57, \quad s d=20$, $\mathrm{RMSEA}=.133$, NFI=.92, NNFI= .91, CFI = .93, IFI=.93, SRMR=066, $\mathrm{GFI}=.90$. Factor load of confirmatory factor analysis were shown in Table-2.

Fit values show that the scale can be adapted to the the Turkish culture with an acceptable degree of adaptability. High values of Rmsea can be associated with the number of the participants. 


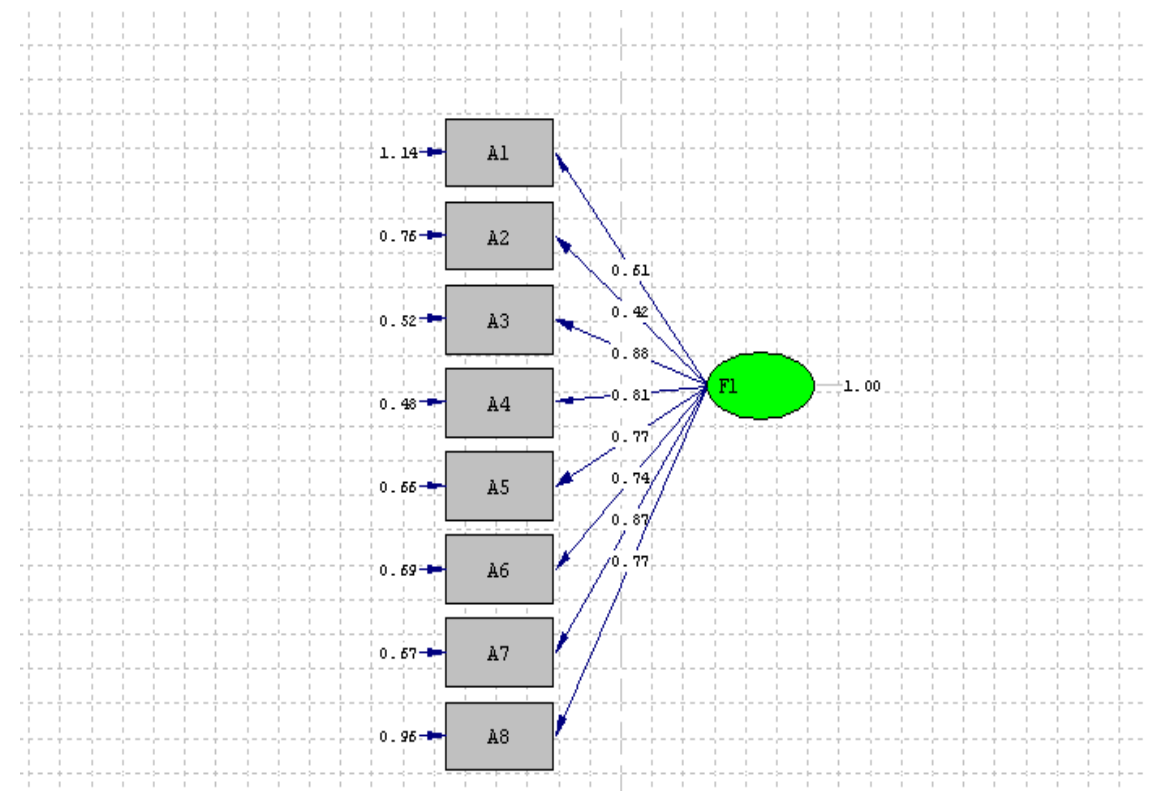

Chi-Square $=97.57, \mathrm{df}=20, \mathrm{P}-\mathrm{value}=0.00000, \mathrm{RMSEA}=0.133$

Table 2. Factor Loads of Confirmatory Factor Analysis

\section{Discussion and Result}

With this study, it was aimed to adapt Perceived School Support Scale in Inclusive Education (PSSSIE) developed by Masud Ahmmed to Turkish and evaluate validity and reliability of Turkish form. The number of the study group meets the required number in the analysis of the validity and reliability (Tabachnick \& Fidell, 2007).PSSSIE's construct validity was examined with Confirmatory Factor Analysis. As a result of CFA, the scale of original form and construct validity of the scale provided were seen. For CFA, when fit index values are considered, it can be stated that model made good fit and original factor structure of the scale conform with Turkish form factor structure. PSSSIE's reliability coefficients being up to the mark shows to meet standards with reliability level of the scale. To use measurement instruments in researches, it must have the required reli- 
ability level .70 (Sipahi, Yurtkoru, \& Çinko, 2008). According to this result, PSSSIE showed above its degree of reliability. Besides, when table of item total correlation was examined, it was seen that all items taking place in the scale exceeded standard .30.About the receiving support for teachers who were tutoring in inclusive education was discussed in a single dimension. Associating each item in the scale with each other and being consistent are very important to measure Perceived School Support in Inclusive Education (PSSSIE). When findings obtained from PSSSIE were seen and were examined in terms of validity and reliability studies, there is no harm in using the scale. As a result of the study, it includes teachers who work at primary, secondary school and having inclusive students. But items in the scale appeal to teachers who works at different type of schools and having inclusive students, also it can be said that this scale can be applied on these groups. Preserving the original form of the scale is applied confirmatory factor analysis (CFA) through the lens, compared with the original form of the validity and reliability values were observed quite close to each other. The comprehensiveness of relevant items in the scale about the support taken by teacher who tutor inclusive education and the application of the scale on teachers who work at different types of schools are crucial to reach wider audience. Reliable and valid results obtained in determining the support received by teachers forming participants of the study, scale necessitates the use of this form. Besides, in the light of findings it is possible to say that the scale is ready to use on different population and samples. But in the research, to expand the type of school makes study more extensive and it can both lead and contribute to the further studies in this field. With this study, it can satisfy the needs of schools, districts, region and our country in application of inclusive education and can recommend solution offers. The result of research findings obtained in this study may provide some suggestions for the contributions to other research be more beneficial: The research has shown that school support in inclusive education applications is crucial. When the results are analyzed, it is noticed that teachers who tutor inclusive education needs more support. Special education requires knowledge and experience. Senior staff planning in service training and informational conferences towards all teachers involved in inclusive education, parents, school administration and other staffs and also nominating experts in this fi- 
eld are quite important. When mainstreaming is not given the necessary support and not creating the necessary environment for education, mainstreaming cannot go more than a name. In this case, inclusive student who is labelled as "mentally retarded" is affected adversely the most.

The study is valuable for the reason that there isn't a research assessing school support in inclusive education. .Therefore, the support received by teachers will affect positively in terms of the quality of inclusive education.

\section{REFERENCES}

Acar, Ç. (2000). Zihin özürlü çocuklarla çalışan özel eğitim öğretmenlerinin sınıflarında karşılaştıkları problem davranışlarla ilgili görüş ve önerileri.(Yayımlanmamış yüksek lisans tezi). Anadolu Üniversitesi/Eğitim Bilimleri Enstitüsü. Eskişehir

Ahmmed,M. (2013). Measuring perceived school support for inclusive education in Bangladesh: the development of a context-specific scale. Asia Pacific Educ. Rev. 14:337-344

Batu, S., Kırcaali-İftar, G. (2007). Kaynaştırma. Ankara: Kök Yayıncılık.

Büyüköztürk, Ş., Kılıç Çakmak, E., Akgün, Ö.E., Karadeniz, Ş. \& Demirel, F. (2012). Bilimsel araştırma yöntemleri. Ankara: Pegem Akademi

Çetrez İşcan, G., Fazlıŏlu, Y., Parlak, C. (2014). İlkokula devam eden normal gelişim gösteren çocukların yetersizliği olan akranlarına yönelik tutumlarının incelenmesi. Abant İzet Baysal Üniversitesi Eğitim Fakültesi Dergisi, 15(Özel Sayl), 128-138.

Demir, M. K., Açar, S. (2011). Kaynaştırma eğitimi konusunda tecrübeli sınıf öğretmenlerinin görüşleri. Kastamonu Eğitim Dergisi, 19, 719-732.

Jöreskog, K. G., Sörbom, D. (1996). LISREL 8: User's reference guide. Scientific Software International.

Kargın,T.(2004). Başmakale: Kaynaştırma: Tanımı, Gelişimi ve İlkeleri. Ankara Üniversitesi $\quad$ Eğitim Bilimleri Fakültesi Özel Ĕ̆itim Dergisi, 5 (2), 1-13. 


\section{S. Arslan, Y. Kılıç / EÜ Ĕ̆itim Fakültesi Dergisi, 18-1 (2016), 1-11}

Kavale, K. A., Forness, S. R. (2000). History, rhetoric, and reality analysis of the inclusion debate. Remedial and Special Education, 21(5), 279-296.

Lindsay, G.(2007). Educational psychology and the effectiveness of inclusive education/mainstreaming. British Journal of Educational Psychology, 77, 1-24.

Sipahi, B.,Yurtkoru, E. S., \& Çinko, M. (2008). Sosyal Bilimlerde SPSS ile Veri Analizi 2. Bası. Beta Basım A.Ş. Istanbul

Tabachnick, B. G.,\&Fidell, L. S. (2007). Using multivariatestatistics. Boston: Pearson/Allyn\& Bacon.

Yigen, S. (2008). Çocuğu İlköğretim Kademesinde Kaynaştırma Uygulamalarina Devam Eden Anne-Babaların Kaynaştırmaya İlişkin Görüş ve Beklentileri. (Yayınlanmamış Yüksek Lisans Tezi). Anadolu Üniversitesi/Eğitim Bilimleri Enstitüsü.Eskişehir. 


\section{Appendix: KAYNAŞTIRMA EĞİTIMİ İÇIN ALGILANAN OKUL DESTEĞİ}

\begin{tabular}{|l|l|l|l|l|l|l|}
\hline & $\begin{array}{l}\text { Sınıf düzeyinde kaynaştırma eğitimini uy- } \\
\text { gulamak için üst düzey yöneticilerden (il- } \\
\text { ilçe milli eğitim müdürü,şube müdürü vb.) } \\
\text { gerekli desteği alırım. }\end{array}$ & 1 & 2 & 3 & 4 & 5 \\
\hline 2 & $\begin{array}{l}\text { Kaynaştırma yoluyla eğitimlerine devam } \\
\text { öğrencilerimin okul eğitimleri ile ilgili } \\
\text { düzenli hizmet içi eğitim alırım. }\end{array}$ & 1 & 2 & 3 & 4 & 5 \\
\hline 3 & $\begin{array}{l}\text { Okulumda kaynaştırma eğitimini uygula- } \\
\text { mak için okul idaresinden destek alırım. }\end{array}$ & 1 & 2 & 3 & 4 & 5 \\
\hline 4 & $\begin{array}{l}\text { Okulumda kaynaştırma eğitimini uygula- } \\
\text { mak için diğer öğretmen arkadaşlarımdan } \\
\text { destek alırım. }\end{array}$ & 1 & 2 & 3 & 4 & 5 \\
\hline 5 & $\begin{array}{l}\text { Okulumda kaynaştırma eğitimini uygula- } \\
\text { mak için, kaynaşırma yoluyla eğitimlerine } \\
\text { devam eden öğrencilerimin ailelerinden } \\
\text { destek alırım. }\end{array}$ & 1 & 2 & 3 & 4 & 5 \\
\hline 6 & $\begin{array}{l}\text { Okulumda kaynaştırma eğitimini uygula- } \\
\text { mak için normal gelişim gösteren öğrencil- } \\
\text { erimin ailelerinden destek alırım. }\end{array}$ & 1 & 2 & 3 & 4 & 5 \\
\hline 7 & $\begin{array}{l}\text { İhtiyaç duyduğumda, özel eğitime ihtiyacı } \\
\text { olan öğrencimin eğitiminde kullanmak için } \\
\text { okuldan gerekli materyal desteği alırım. }\end{array}$ & 1 & 2 & 3 & 4 & 5 \\
\hline 8 & $\begin{array}{l}\text { Gerektiğinde kaynaştırma eğitimi ile ilgili } \\
\text { özel eğitim öğretmenlerinden destek alırım. }\end{array}$ & 1 & 2 & 3 & 4 & 5 \\
\hline
\end{tabular}

